\title{
HUBUNGAN TINGKAT PENDIDIKAN PEREMPUAN DAN ORANG TUA DENGAN PERNIKAHAN PEREMPUAN USIA DINI

\author{
${ }^{1}$ Dewi Susanti, ${ }^{2}$ Wulan Mayang Sari \\ Program Studi Kebidanan, Politeknik Kesehatan Kemenkes Padang \\ Jl. Raya Siteba, Surau Gadang, Nanggalo, Kota Padang, Sumatera Barat. 25146 \\ Email : dewipoltekkespadang@gmail.com \\ wulanmayangsari@gmail.com
}

\section{Abstrak}

Berdasarkan Survey Unicef tahun 2014 Indonesia peringkat ke-37 kejadian PPUD di dunia. Sumatra Barat dari tahun 2010-2015 tercatat 6.083 pasangan melakukan PPUD. Tanah Datar peringkat ke-10 dan Nagari Singgalang peringkat pertama kejadian PPUD. Salah satu Faktor yang mempengaruhi PPUD seperti tingkat pendidikan perempuan dan pendidikan orang tua. Tujuan penelitian mengetahui Hubungan Tingkat Pendidikan Perempuan dan Orang Tua dengan Pernikahan Perempuan Usia Dini Nagari Singgalang Kecamatan X Koto Kabupaten Tanah Datar Tahun 2017. Jenis penelitian adalah survey analitik dengan desain cross sectional, dilaksanakan pada tanggal 06-08 April 2017 di Nagari Singgalang. Populasi pada penelitian ini adalah perempuan yang menikah dari tahun 2015-Juli 2016 sebanyak 143 orang. Besar sampel ditentukan dengan rumus Infinit sebanyak 58 orang diambil dengan teknik purposive sampling. Data primer dikumpulkan dengan cara wawancara. Analisis data secara univariat menggunakan metode presentase dan analisis bivariat menggunakan uji chi-square dengan $\alpha$ 0,05. Hasil penelitian didapatkan perempuan dengan tingkat pendidikan rendah 86,2\%, orang tua dengan tingkat pendidikan rendah $89,7 \%$ dan pernikahan perempuan usia dini $63,8 \%$. Hasil analisis bivariat ada hubungan antara tingkat pendidikan perempuan dengan PPUD ( $p$ value $=0,021<0,05)$ dan ada hubungan antara tingkat pendidikan orang tua dengan PPUD ( $p$ value $=0,020<0,05$ ).

Kata kunci: PPUD, Pendidikan Perempuan, Pendidikan orang tua

\section{RELATIONSHIP OF EDUCATION WOMEN AND PARENTS WITH EARLY WOMEN WEDDING}

\begin{abstract}
A survey by UNICEF in 2014 reporting Indonesia ranked as the $37^{\text {th }}$ country that has justified towards the early marriage. In West Sumatera from 2010-2015, there were 6083 couples do the early marriage. Tanah Datar District ranked as the 10th, and Nagari Singgalang is the $1^{\text {st }}$ ranked for early marriage. Some factors affected early marriage such as the education level of women and parents education level. The research method is an analytic survey with a cross-sectional design, held from 6-8 April 2017 in Nagari Singgalang. In population, this study is women who got married from 2015-July 2016 for about 143 people. The sample size is determined by the formula infinite with the number of 58 people were taken by purposive sampling technique. Primary data was collected by interview. Data were analyzed by univariate in the percentages form and bivariate analysis using the chi-square test with $\alpha$ of 0.05. The result showed $86,2 \%$ of respondents have low education levels, $89.7 \%$ of respondents parents have low education levels, and $63.8 \%$ of respondents were married in unappropriate age/early marriage. The results of bivariate analysis, a relations between education level with the early marriage ( $p$ value= $0.021<0.05)$ and a relations between parents education level with the early marriage $(p$ value $=$ $0.020<0.05)$.
\end{abstract}

Keywords: Early marriage, women's education, parents education 


\section{PENDAHULUAN}

Menurut United Nations International Children's Emergency Fund (UNICEF), Pernikahan dini (early meriage) adalah suatu pernikahan formal atau nonformal yang dilakukan di bawah usia 18 tahun. Pernikahan usia reproduktif yaitu lebih dari 20 tahun jika (Ma'mun, 2015).

Perempuan yang melakukan pernikahan pada usia dini memiliki waktu lebih banyak untuk hamil dan bersalin dibanding perempuan menikah usia tua. Hasil peneitian Nandang, dkk (2007) menunjukkan bahwa remaja muda yang berpendidikan rendah di kelurahan mekarsari memiliki risiko (ods ratio) 4,259 kali menikah dini dari pada remaja muda yang berpendidikan tinggi. (Dkk, 2017) Di tiap Negara memiliki bermacam-macam variasi pernikahan dini. Terlihat pada International Center for Research on Women (ICRW) 2013, terdapat 51 juta anak perempuan telah menikah pada usia 15-19 tahun. menurut

Perserikatan Bangsa- Bangsa (PBB) memprediksikan lebih dari 140 juta anak perempuan akan menikah dalam satu dekade menjelang tahun 2020. (Rafidah dkk, 2012) HaI ini setara dengan 14 juta pengantin anak setiap tahun atau hampir 39.000 perempuan menikah setiap hari. Menurut Laporan Kantor Urusan Agama Kecamatan X Koto Kabupaten Tanah Datar, Nagari Singgalang pada tahun 2013 sampai 2015 didapatkan perempuan yang menikah usia dini sebanyak 102 (37,2\%) dari 274 perempuan yang menikah. Studi pendahuluan yang dilakukan kepada 8 perempuan yang menikah di Nagari Singgalang pada Agustus 2016, 5 responden menikah pada usia $<20$ tahun, 3 responden menikah pada usia $>20$ tahun, 5 responden berpendidikan rendah dan 3 responden memiliki orang tua dengan tingkat pendidikan rendah.

\section{METODE PENELITIAN}

Jenis penelitian yang digunakan yaitu survey analitik dengan desain cross sectional. Penelitian ini menggali tentang fenomena yang terjadi, kemudian menganalisa hubungan antara variabel dan independen, yang dilakukan satu kali secara bersamaan saat penelitian dilaksanakan. Variabel dependen penelitian ini adalah pernikahan perempuan usia dini, sedangkan variabel tingkat pendidikan perempuan dan tingkat pendidikan orang tua. Yang dilakukan di bulan Agustus 2016 sampai
April 2017 di Nagari Singgalang Kecamatan X Koto Kabupaten Tanah Datar.

\section{HASIL DAN PEMBAHASAN}

Berdasarkan hasil penelitian yang dilakukan tentang hubungan tingkat pendidikan perempuan dan tingkat pendidikan orang tua dengan pernikahan perempuan usia dini di nagari singgalang kecamatan $\mathrm{X}$ koto kabupaten tanah datar tahun 2017. dengan jumlah 58 orang wanita PUS.

Tabel 1. Distribusi Frekuensi Pernikahan Perempuan Usia Dini di Nagari Singgalang Kecamatan $X$ Koto Kabupaten Tanah Datar Tahun 2017

\begin{tabular}{cccc}
\hline No & Pernikahan Perempuan & f & $\mathbf{\%}$ \\
\hline 1. PPUD & 37 & 63,8 \\
2. Tidak PPUD & 21 & 36,2 \\
\hline Jumlah & 58 & 100 \\
\hline \multicolumn{2}{r}{ Hasil penelitian terhadap } & 58 orang
\end{tabular}

perempuan yang menikah tahun 2015- Juli 2016 di Nagari Singgalang Kecamatan $X$ Koto Kabupaten Tanah Datar, menunjukkan bahwa $37(63,8 \%)$ perempuan menikah pada usia dini. Hasil penelitian ini sesuai dengan penelitian Lusi amrawiyata (2009) dengan judul faktorfaktor yang berhubungan dengan perkawinan usia muda di Kecamatan Koto Tangah Padang, dimana lebih dari setengah $(61,4 \%)$ responden menikah pada usia dini.(lusi Pohan, Kebidanan and Bagan, 2017) Penelitian ini relevan dengan penelitian Rafidah, dkk (2014) dengan judul faktor-faktor yang mempengaruhi pernikahan usia dini di Kabupaten Banjar menyatakan dari 102 responden, lebih dari setengah $(53,9 \%)$ responden menikah pada usia dini.(Rafidah dkk, 2012)

Penelitian Rafidah, dkk memiliki kesamaan metode penelitian dan desain penelitian yang dilakukan oleh peneliti yaitu metode penelitian survey analitik dan desain cross sectional. Namun ada perbedaan penelitian Rafidah dkk dengan penelitian ini yaitu penelitian Rafidah dilakukan dengan membagi kuesioner dan wawancara mendalam langsung kepada responden sementara penelitian ini hanya membagikan kuesioner langsung kepada responden. Pernikahan merupakan ikatan lahir bathin antara seorang pria dan wanita sebagai suami istri dengan tujuan untuk membentuk keluarga yang bahagia dan kekal berdasarkan Ketuhanan Yang Maha Esa.(Kusumawati, 2013) Usia menikah 
dianggap paling ideal bagi perempuan adalah umur 20 tahun karena secara fisik organ reproduksi sudah cukup matang dan secara psikologis sudah siap berumah tangga.

Pernikahan yang dilakukan pasangan yang berusia terlalu dini secara psikologis belum menunjukkan kematangan secara mental karena jiwanya masih labil yang dipengaruhi oleh keinginannya untuk bergaul secara bebas dengan teman-teman seusianya, sehingga belum memiliki kesiapan untuk mengurus keluarga. Pernikahan usia dini mencerminkan rendahnya status perempuan, dan juga merupakan tradisi sosial yang menopang tingginya angka kelahiran. Hal ini dikarenakan periode melahirkan yang dihadapi oleh pengantin remaja relatif lebih panjang. Pernikahan dini mempunyai dampak yang serius bagi perempuan terhadap kesehatan, psikologis dan lingkungan sosial. Perempuan yang menikah pada usia dini cenderung memiliki risiko pada saat kehamilan karena organ reproduksi yang belum siap menerima kehamilan. Kurang matangnya kesiapan kejiwaan dan emosi, pernikahan dini sering menimbulkan perasaan gelisah, mudah timbul rasa curiga sehingga pertengkaran antara suami istri sering terjadi.

Perlu diadakannya penyuluhan oleh tenaga kesehatan kepada masyarakat, orang tua dan remaja tentang risiko pernikahan usia dini serta pendewasaan usia pernikahan sehingga tidak ada lagi perempuan di Nagari Singgalang yang menikah pada usia dini untuk kedepannya dan bagi perempuan yang telah melakukaan pernikahan usia dini diharapkan untuk menunda kehamilannya dengan menggunakan alat kontrasepsi agar terhindar dari risiko kesakitan dan kematian pada saat kehamilan, persalinan, nifas serta bayinya.

Tabel 2. Distribusi Frekuensi Tingkat Pendidikan Perempuan di Nagari Singgalang Kecamatan $X$ Koto Kabupaten Tanah Datar Tahun 2017

\begin{tabular}{|c|c|c|c|}
\hline No & $\begin{array}{l}\text { Tingkat Pendidikan } \\
\text { Perempuan }\end{array}$ & f & $\%$ \\
\hline & Rendah & 50 & 86,2 \\
\hline & Tinggi & 8 & 13,8 \\
\hline Jumla & & 58 & 100 \\
\hline $\begin{array}{l}\text { perer } \\
\text { di } ~ \\
\text { Kabu } \\
50 \text { or } \\
\text { Pene }\end{array}$ & $\begin{array}{l}\text { Hasil penelitian te } \\
\text { npuan yang menikah ta } \\
\text { Jagari Singgalang Ke } \\
\text { paten Tanah Datar, m } \\
\text { ang }(86,2 \%) \text { memiliki } \\
\text { litian ini sesuai dengan }\end{array}$ & $\begin{array}{l}\text { 15- } \\
\text { in } \\
\text { kka } \\
\text { ika }\end{array}$ & $\begin{array}{l}\text { orang } \\
2016 \\
\text { Koto } \\
\text { ahwa } \\
\text { ndah } \\
\text { affak }\end{array}$ \\
\hline
\end{tabular}

(2013) dengan judul pengaruh tingkat pendidikan dan ekonomi terhadap pola keputusan orang tua untuk mengawinkan anaknya di desa karang duwak kecamatan arosbaya kabupaten bengkalan juga menyatakan $91 \%$ responden memiliki pendidikan rendah.(Studi et al., 2006)

Penelitian ini relevan dengan penelitian Amelia Sari 2014 dengan judul faktor-fakor yang berhubungan dengan pernikahan perempuan usia dini yang dilakukan oleh orang tua di wilayah kerja Puskesmas Belimbing Kota Padang menyatakan sebanyak $78 \%$ responden memiliki tingkat pendidikan rendah.(Dkk, 2014) Penelitian Amelia memliki kesamaan dengan penelitian yang dilakukan oleh peneliti yaitu sama-sama menggunakan metode survey analitik dan desain cross sectional. Namun ada perbedaan dari sampel, penelitian Amelia sampelnya yaitu orang tua yang telah melakukan pernikahan dini sebanyak 100 orang sementara penelitian ini sampelnya yaitu perempuan yang menikah dua tahun terakhir sebanyak 58 orang.

Tingkat pendidikan seseorang sangat mempengaruhi dalam menyikapi masalah dan membuat keputusan termasuk hal yang lebih kompleks atau kematangan sosial. Remaja khususnya perempuan mempunyai kesempatan yang lebih kecil untuk mendapatkan pendidikan formal dan pekerjaan yang pada akhirnya mempengaruhi kemampuan pengambilan keputusan dari pemberdayaan untuk menunda pernikahan.(Desiyanti, 2015)

Pendidikan yang rendah akan berakibat putusnya informasi yang diperoleh pada jenjang pendidikan yang lebih tinggi. pendidikan yang rendah membuat seseorang tdak dapat berfikir maju. Rendahnya pendidikan disebabkan karena kemauan remaja yang kurang untuk melanjutkan pendidikan yang tinggi. Hal ini menyebabkan perempuan yang memiliki pendidikan rendah cenderung dinikahkan oleh orang tuanya dibandingkan perempuan yang memiliki pendidikan tinggi karena dalam kekosangan waktu tanpa aktivitas membuat mereka melakukan hal-hal yang tidak produktif, salah satu contoh adalah menjalin hubungan dengan lawan jenis, yang jika diluar kontrol diri akan memungkinkan terjadinya kehamilan diluar nikah.

Oleh disebab itu, diharapkan kepada orang tua agar mendukung dan memotivasi anaknya untuk mendapatkan pendidikan yang tinggi karena pendidikan sangat berpengaruh terhadap pengambilan keputusan. Serta 
diharapkan kepada pihak-pihak yang terkait dengan bidang pendidikan agar lebih memotivasi dan memberikan fasilitas kepada masyarakat, sehingga tidak ada lagi alasan bagi masyarakat untuk tidak bersekolah atau berpendidikan.

Tabel 3. Distribusi Frekuensi Tingkat Pendidikan Orang Tua Responden di Nagari Singgalang Kecamatan $X$ Koto Kabupaten Tanah Datar Tahun 2017

\begin{tabular}{cccc}
\hline No & $\begin{array}{c}\text { Tingkat Pendidikan } \\
\text { Orang Tua }\end{array}$ & f & \% \\
\hline $1 . \quad$ Rendah & 52 & 89,7 \\
2. Tinggi & 6 & 10,3 \\
\hline Jumlah & 58 & 100 \\
\hline
\end{tabular}

Hasil penelitian terhadap 58 orang perempuan yang menikah tahun 2015- Juli 2016 di Nagari Singgalang Kecamatan X Koto Kabupaten Tanah Datar, diperoleh 52 (89,7\%) orang tua responden memiliki tingkat pendidikan rendah. Hasil penelitian ini sesuai dengan penelitian Tri Ayu Setiowati (2015) dengan judul gambaran karakteristik perempuan yang menikah usia dini di Kecamatan Banguntapan Bantul Yogyakarta, dimana lebih dari setengah $(66,7 \%)$ responden memiliki ayah dengan status pendidikan rendah.(Karakteristik et al., 2015) Perbedaan penilitian ini dengan penelitian yang dilakukan oleh Tri Ayu adalah sampel penelitian Tri Ayu lebih sedikit yaitu sebanyak 42 responden sedangkan penelitian ini sampelnya sebanyak 58 orang. Pendidikan merupakan salah satu faktor mempengaruhi presepsi seseorang, dengan pendidikan tinggi seseorang akan lebih mudah menerima atau memilih suatu perubahan yang lebih baik.

Tingkat pendidikan menggambarkan tingkat kematangan kepribadian seseorang dalam merespon lingkungan yang dapat mempengaruhi wawasan berfikir atau merespon pengetahuan yang ada disekitarnya.(Rafidah dkk, 2012) Dari hasil penelitian menunjukkan sebagian besar tingkat pendidikan orang tua responden rendah. Tingkat pendidikan rendah menyebabkan sebagian orang tua tidak mengetahui bahwa pemerintah telah mengeluarkan kebijakan wajib belajar 12 tahun. Sehingga, masih banyak orang tua yang memutuskan untuk tidak melanjutkan pendidikan anaknya. Oleh sebab itu, diharapkan kepada orang tua untuk lebih memiliki motivasi dan kemauan untuk melanjutkan pendidikan anaknya, karena pendidikan merupakan sumber di dalam memperoleh segala ilmu pengetahuan dan sangat mempengaruhi didalam pengambilan keputusan termasuk keputusan kapan untuk menikah.

Tabel 4. Distribusi Frekuensi Hubungan Tingkat Pendidikan Perempuan dengan Pernikahan Perempuan Usia Dini di Nagari Singgalang Kecamatan X Koto Kabupaten Tanah Datar Tahun 2017

\begin{tabular}{cccccccc}
\hline \multirow{2}{*}{$\begin{array}{c}\text { Tingkat } \\
\text { Pendidikan } \\
\text { Perempuan }\end{array}$} & \multicolumn{4}{c}{ Pernikahan Perempuan } & Jumlah \\
\cline { 2 - 7 } & PPUD & \multicolumn{4}{c}{ Tidak PPUD } & & \\
\cline { 2 - 7 } & f & \% & f & \% & f & \% \\
\hline Rendah & 35 & 70,0 & 15 & 30,0 & 50 & 100 \\
Tinggi & 2 & 25.0 & 6 & 75,0 & 8 & 100 \\
\hline Jumlah & 37 & 63,8 & 21 & 36,2 & 58 & 100 \\
\hline
\end{tabular}

Hasil penelitian yang telah dilakukan, diketahui bahwa dari 50 responden yang memiliki pendidikan rendah $70,0 \%$ menikah pada usia dini. Setelah dilakukan hasil uji statistik chi-square diperoleh nilai $p$ value $=$ $0,01(p<0.05)$, nilai ini menunjukkan bahwa terdapat hubungan antara tingkat pendidikan dengan pernikahan perempuan usia dini di Nagari Singgalang Kecamatan $X$ Koto Kabupaten Tanah Datar. Hal ini sesuai dengan penelitian Amelia sari (2014) menunjukkan terdapat hubungan antara tingkat pendidikan dengan pernikahan usia dini dengan nilai $p$ value $=0,001 .(\mathrm{Dkk}, 2014)$

Penelitian ini relevan dengan penelitian yang dilakukan oleh Kusumawati,Riski (2013) menunjukkan ada hubungan antara tingkat pendidikan dengan pernikahan usia dini ( $p$ value $=0,000)$. (Kusumawati, 2013) Namun, ada perbedaan dari metode penelitian, penelitian Kusumawati menggunakan metode penelitian studi dokumentasi karena data diperoleh dengan cara wawancara dengan petugas KUA dan mengambil data sekunder dari buku registrasi pernikahan sementara penelitian ini menggunakan metode survey analitik. Teknik pengambilan sampel oleh Kusumawati menggunakan total sampling sementara penelitian ini menggunakan teknik pengambilang sampel purposive sampling. Berdasarkan hasil penelitian Nandang, dkk (2007) yang berjudul faktor- faktor yang berhubungan dengan usia nikah muda pada wanita dewasa muda di Kelurahan Mekarsari kota Bandung menunjukkan bahwa remaja muda yang berpendidikan rendah memiliki ods ratio 4,259 kali menikah dini daripada remaja 
muda yang berpendidikan tinggi.(Dkk, 2017) Penelitian lainnya oleh Desiyanti (2014) tentang faktor-faktor yang berhubungan dengan pernikahan pada pasangan usia subur menunjukkan bahwa terdapat hubungan antara pendidikan responden dengan kejadian pernikahan dini, responden yang memiliki pendidikan rendah berpeluang lebih besar untuk melakukan pernikahan dini dibandingkan responden yang memiliki pendidikan tinggi.(Desiyanti, 2015)

Tingkat pendidikan seseorang sangat mempengaruhi dalam menyikapi masalah dan membuat keputusan termasuk hal yang lebih kompleks atau kematangan sosial. Tingkat pendidikan yang rendah dapat menyebabkan kecenderungan melakukan pernikahan usia dini. Semakin tinggi pendidikan maka akan semakin besar pengetahuan yang didapatkan. Perempuan dengan latar belakang pendidikan tinggi memliki risiko lebih kecil untuk melakukan pernikahan dini dibandingkan perempuan dengan berlatar belakang pendidikan rendah karena pengetahuan yang didapatkannya lebih banyak.(Desiyanti, 2015)

Perempuan merupakan individu yang paling birisiko melakukan pernikahan dini karena alat reproduksinya belum siap menerima kehamilan sehingga dapat menimbulkan berbagai komplikasi dan secara psikologis belum matang sehingga cenderung labil dan emosional. Pernikahan dini menimbulkan anak rentan terhadap kekerasan dalam rumah tanggga, berisiko dua kali lipat mendapatkan kanker serviks, dan meningkatkan angka kesakitan dan kematian ibu akibat komplikasi kehamilan (abortus,anemi) dan persalinan (pendarahan, persalinan yang lama), serta anak yang dilahirkan berisiko mengalami BBLR Selain itu, menikah dini meningkatkan jumlah perceraian karena kurangya kesadaran tanggung jawab dalam kehidupan berkeluarga.(Dkk, 2018) Tingkat pendidikan yang rendah menyebabkan rendahnya pengetahuan orang tua, anak, masyarakat tentang dampak pernikahan di usia dini. Makin rendah tingkat pendidikan remaja makin sering terjadi pernikahan di usia dini. Peran tingkat pendidikan berhubungan erat dengan pemahaman tentang berkeluarga. Dengan kata lain, pendidikan adalah akar dari semua masalah pada diri individu, karena dari pendidikan individu akan memperolah pengetahuan untuk menentukan sikapnya dalam mengambil keputusan. Termasuk mengambil keputusan apakah diri mereka siap atau tidak menikah dan menjadi ibu di usia yang masih sangat dini. Pernikahan dini seringkali menyebabkan anak tidak lagi bersekolah, karena kini ia mempunyai tanggung jawab baru, yaitu sebagai istri dan calon ibu, dan lebih banyak mengurus rumah tangga serta anak yang akan hadir. Pola lainya yaitu, kurang berminatnya remaja untuk melanjutkan pendidikan yang lebih tinggi dengan berbagai alasan menyebabkan orang tua memutuskan untuk menikahkan anaknya. Ditambah lagi orang tua individu yang juga memiliki pendidikan rendah bisa mendorong terjadinya pernikahan usia dini pada anak akibat kurangnya pengetahuan orang tua tentang dampak dari pernikahan dini. Lain halnya jika orang tua memiliki pendidikan tinggi tentu mereka bisa memberi pemahaman kepada anaknya untuk tidak menikah pada usia dini. Disamping itu, hadirnya program pemerintah wajib belajar sembilan tahun, seharusnya mampu menghapuskan putus sekolah, sehingga tidak ada lagi remaja yang tidak bisa bersekolah dengan alasan apapun. Namun kenyataan dari hasil penelitian diperolah $86,2 \%$ responden masih memiliki pendidikan rendah dimana hal itu menunjukkan masih lebih dari seten gah responden memiliki pendidikan rendah. Oleh karena itu, dibutuhkan bantuan dinas pendidikan untuk mampu menyukseskan program wajib belajar sembilan tahun, bahkan berupaya untuk melaksanakan program wajib belajar dua belas tahun di Kecamatan X Koto Kabupaten Tanah Datar.

Tabel 5. Distribusi Frekuensi Hubungan Tingkat Pendidikan Orang Tua dengan Pernikahan Perempuan Usia Dini di Nagari Singgalang Kecamatan X Koto Kabupaten Tanah Datar Tahun 2017

\begin{tabular}{|c|c|c|c|c|c|}
\hline \multirow{3}{*}{$\begin{array}{c}\text { Tingkat } \\
\text { Pendidikan } \\
\text { Orang Tua }\end{array}$} & \multicolumn{3}{|c|}{ Pernikahan Perempuan } & \multirow{2}{*}{\multicolumn{2}{|c|}{ Jumlah }} \\
\hline & PPUD & \multicolumn{2}{|c|}{ Tidak PPUD } & & \\
\hline & f $\%$ & f & $\%$ & f & $\%$ \\
\hline Rendah & 3669,2 & 16 & 30,8 & 52 & 100 \\
\hline Tinggi & 116,7 & 5 & 83,3 & 6 & 100 \\
\hline Jumlah & 3763,8 & 21 & 36,2 & 58 & 100 \\
\hline
\end{tabular}

Diketahui bahwa dari 52 orang tua responden yang memiliki pendidikan rendah 69,2\% melakukan pernikahan usia dini pada anaknya. Setelah dilakukan hasil uji statistik chisquare diperoleh nilai $p$ value $=0,020(p<0.05$ ), nilai ini menunjukkan bahwa terdapat hubungan antara tingkat pendidikan orang tua 
dengan pernikahan perempuan usia dini di Nagari Singgalang Kecamatan X Koto Kabupaten Tanah Datar. Hal ini sesuai dengan penelitian yang dilakukan oleh Irne W. Desiyanti (2015) yang berjudul faktor-faktor yang berhubungan terhadap pernikahan dini pada pasangan usia subur di Kecamatan Mapanyet Kota Manado bahwa terdapat hubungan antara tingkat pendidikan orang tua dengan pernikahan usia dini dengan $p$ value $=$ 0,003.(Desiyanti, 2015) Perbedaan penelitian ini dengan penelitian yng dilakukan oleh Irne yaitu penelitian Irne menggunakan uji regresi logistik berganda yang digunakan untuk mencari faktor yang paling dominan (variabel bebas) mempengaruhi variabel terikat sedangkan penelitian ini hanya menggunakan uji chi square untuk mengetahui hubungan variabel bebas dengan variabel terikat.

Pendidikan merupakan salah satu faktor mempengaruhi presepsi seseorang, dengan pendidikan tinggi seseorang akan lebih mudah menerima atau memilih suatu perubahan yang lebih baik. Tingkat pendidikan menggambarkan tingkat kematangan kepribadian seseorang dalam merespon lingkungan yang dapat mempengaruhi wawasan berfikir atau merespon pengetahuan yang ada disekitarnya. Hasil penelitian menunjukkan sebagian besar orang tua responden memiliki pendidikan rendah, sehingga pengetahuan orang tua responden terhadap risiko perniakan dini sangat minim. Hal ini, sesuai dengan penelitian yang dilakukan Martino (2004) menyatakan bahwa tingkat pendidikan orang tua sangat mempengaruhi anaknya untuk melakukan pernikahan usia dini, karena orang tua yang memiliki pendidikan rendah kurang memiliki pengetahuan dan wawasan tentang dampak dari pernikahan dini sehingga orang tua juga mendukung anaknya untuk melakukan pernikahan dini. Selain itu, tingkat pendidikan juga mempengaruhi pemahaman keluarga tentang berkeluarga yang lebih baik.

Orang tua yang memiliki pemahaman rendah terhadap kehidupan berkeluarga akan memandang bahwa dalam kehidupan berkeluarga akan tercipta suatu hubungan yang baik, sehingga pernikahan yang makin cepat adalah solusi utama bagi orang tua. Ayah merupakan kepala keluarga yang sangat memiliki andil besar di dalam pengambilan keputusan dalam keluarga termasuk keputusan untuk menikahkan anaknya pada usia dini.

Pada penelitian ini rata-tara tingkat pendidikan ayah responden rendah, sehingga ayah responden rata-rata memiliki pengetahuan yang rendah terhadap risiko dari pernikahan dini. Ditambahlagi, dengan pemikiran ayah responden jika anaknya tidak bersekolah lagi, tidak bekerja dan untuk menghindari berbagai macam pengaruh pergaulan, ayah responden cenderung memutuskan untuk menikahkan anaknya tampa memikirkan usia. Disamping itu, ayah yang memiliki tingkat pendidikan rendah cenderung memiliki pemahaman yang kurang tentang kehidupan berkeluarga karena mereka memandang jika dengan segera menikahkan anaknya akan tercipta hubungan silaturahmi yang baik di kedua belah pihak keluarga. Sosialisasi perlu dilaksanakan secara berkelanjutan oleh instasi terkait dalam hal pencegahan dan mengatasi dampak dari pernikahan dini khususnya masyarakat Nagari Singgalang. Perlu proses pengembangan kurikulum pendidikan kesehatan tentang dampak dan resiko dari pernikahan dini terhadap remaja Indonesia.

\section{UCAPAN TERIMAKASIH}

Terima kasih terutama kepada Allah SWT, selanjutnya terimakasih kepada berbagai pihak yang membantu peneliti selama pembuatan penelitian. sehingga peneliti dapat menyelesaikan penelitian ini.

\section{DAFTAR PUSTAKA}

Desiyanti, I. W. (2015) 'Faktor-Faktor yang Berhubungan Terhadap Pernikahan Dini Pada Pasangan Usia Subur di Kecamatan Mapanget Kota Manado Factors Associated With Early Mariage In Couples Of Childbearing Age At Kecamatan Mapanget Manado City', pp. 270-280.

Dkk, nina sopiyana (2014) '160 Jurnal Dunia Kesmas Volume 3. Nomor 3. Juli 2014', 3, pp. 160-166.

Dkk, A. prihatining rahayu (2018) 'Resiko Kekerasan Dalam Rumah Tangga ( Kdrt ) Pada Pernikahan Usia Anak Di Kawasan Marginal Surabaya ( Studi Kasus di Kelurahan Nyamplungan , Paben Cantikan, Surabaya ) pendahuluan Pernikahan anak atau pernikahan usia dini tidak hanya menjadi persoalan di’, 4, pp. 80-92.

Lubis, Namora Lumongga. Psikologi Kespro Wanita \& Perkembangan Reproduksinya. 
Cetakan Kedua. Jakarta: Prenadamedia Group; 2016

Dkk, N. (2017) 'faktor-faktor yang berhubungan dengan usia menikah muda pada wanita dewasa muda', p. 63.

Karakteristik, G. et al. (2015) 'Gambaran Karakteristik Perempuan Yangmenikah Usia Dini Di Kecamatan Banguntapan Bantul Yogyakarta'.

Kusumawati, riski danik (2013) 'Hubungan Tingkat Pendidikan Dengan Kejadian Pernikahan Dini Pada Wanita Dibawah Umur 21 Tahun Di Desa Keboromo Kecamatan Tayu Kabupaten PATI'.

lusi Pohan, N. H., Kebidanan, A. and Bagan, U. (2017) 'Faktor yang berhubungan dengan pernikahan usia dini terhadap remaja putri', 2(October), pp. 424-435.

Ma'mun, M. S. (2015) 'Faktor Pendorong Pernikahan Dini Di Kabupaten Banyuwangi', p. 2015.

Rafidah dkk (2012) 'Faktor-Faktor Yang Mempengaruhi Pernikahan Usia Dini Di Kabupaten Banjar'.

Studi, P. et al. (2006) 'Di Desa Karang Duwak Kecamatan Arosbaya Kabupaten Bangkalan Muzaffak', pp. 1-8 